\title{
КАФКА И ГОГОЛЬ: ЗАМОК И ВИЙ
}

\author{
СЕРГЕЙ ШУЛЬЦ \\ (независимый исследователь) \\ Ростов-на-Дону, Россия \\ e-mail: s_shulz@mail.ru \\ ORCID: https://orcid.org/0000-0002-3429-6714 \\ (получено 31.12.2017; принято 20.09.2018)
}

\section{Abstract \\ Kafka and Gogol: Schloss and Vij}

The question is raised about the relationship between Gogol's short story "Viy" and Kafka's novel "The Castle”. When comparing the texts of Gogol and Kafka, the author focuses on elements of Menippean satire (in the broadest sense, not only as a genre). The chronotope of the works, as well as their historiosophic meaning (perception of infernality; orientation towards the fate of Europe, especially noticeable in Kafka) are considered.

\section{Key words}

Gogol, Kafka, Menippean satire, carnivalization, infernality, the destiny of Europe.

\section{Резюме}

Ставится вопрос о перекличках между повестью Гоголя Вий и романом Кафки Замок. При сопоставлении текстов Гоголя и Кафки во главу угла поставлено мениппейное начало (в самом широком плане, не только узкожанровом). Рассмотрены хронотопические планы произведений, их историософский смысл (восприятие инфернальности; обращенность к судьбе Европы, особенно заметная у Кафки). 


\section{Ключевые слова}

Гоголь, Кафка, мениппейное начало, карнавализация, инфернальность, судьба Европы.

Параллели между творчеством Гоголя и Кафки проводятся нередко (см., напр.: Parry, 1953; Fetzer, Lawson, 1978; Манн, 1999, 2007; Иваницкий, 2000; и др.), основанием для чего служат одинаково присущие двум писателям сочетание серьезности и комизма, религиозно-философской устремленности в скрещении с бытовизмом, трагический гротеск и т.п. Приведенный набор качеств во многом присущ мениппее, как ее описал Бахтин в качестве серьезно-смехового, карнавализованного жанра. Мениппейное начало (в самом широком плане: не только узкожанровом, но в плане общей культурфилософии) поставим во главу угла при сопоставлении текстов Гоголя и Кафки, в частности, Вия и Замка ${ }^{1}$.

В аспекте „философии имени” любопытно уже совпадение „птичьих” фамилий двух мистических писателей: гоголь - вид птиц семейства утиных, kavka почешски означает „галка”. Принципиально наличие у Кафки общего с Гоголем „птичьего кода” карнавализованной автосимволизации и автомифологизации.

Гоголь придавал своей фамилии (в ее внутренней форме) символическо-онтологическое значение, например, „вставляя” ее в качестве обозначения героя„птицы” в свои художественные тексты и вообще рассматривая собственные произведения (особенно Мертвые души) в качестве своеобразного „магического” развертывания своего „птичьего имени” (см.: Шульц, 2017).

Кафка нарочито подчеркивал внутреннюю форму своей фамилии в беседе с Яноухом, хотя с долей трагической и вместе с тем карнавализованной иронии른

Творчество для художника - страдание, посредством которого он освобождает себя для нового страдания. Он не исполин, а только пестрая птица, запертая в клетке собственного существования.

- И вы тоже?

- Я совершенно несуразная птица. Я - Kavka, галка. У угольщика в Тайнхофе есть такая. Вы видели ее?

- Да, она скачет около тавки.

- Этой моей родственнице живется лучше, чем мне. Правда, у нее подрезаны крылья... (Кафка, 1991, с. 546)

И далее следует практически прямое символически-мистическое развертывание самотрактовки через птичий облик:

1 По отношению к Процессу термин мениппея использован, например, в: Лескова, 2015.

2 Характерное для Кафки соединение карнавального и трагического встречается, например, в его примечательной дневниковой записи (30 августа 1912 г.): „Когда я сегодня после обеда лежал в кровати и кто-то быстро повернул ключ в замке, мне показалось, будто все мое тело в замках, как на карнавальном костюме, и с короткими интервалами то тут, то там открывался или запирался какой-нибудь из замков" (Кафка, 1991, с. 490). 
Со мной этого делать не надобно, ибо мои крылья отмерли. И теперь для меня не существует ни высоты, ни дали. Смятенно я прыгаю среди людей. (...) Я ведь опасная птица, воровка, галка. Но это лишь видимость. (...) Поэтому у меня нет даже блестящих черных перьев. Я сер, как пепел. Галка, страстно желающая скрыться среди камней. Но это так, шутка...

(Кафка, 1991, с. 546)

Признание Кафкой своих крыльев „отмершими” корреспондирует образу из постромантического/модернистского стихотворения Бодлера Альбатрос, где даже поверженная птица выделяется среди обычных существ своим внутренним масштабом и значением:

И вот, когда царя любимого лазури

На палубе кладут, он снежных два крыла,

Умевших так легко парить навстречу бури,

Застенчиво влачит, как два больших весла

Быстрейший из гонцов, как грузно он ступает!

Краса воздушных стран, как стал он вдруг смешон!

(...) Поэт, вот образ твой! Ты также без усилья

Летаешь в облаках, средь молний и громов,

Но исполинские тебе мешают крылья

Внизу ходить, в толпе, средь шиканья глупцов.

(Бодлер, 1993, с. 47)

Неверны расставленные Подорогой акценты, согласно которым в кафковской самотрактовке заметно лишь „последовательное движение регрессии от образа птицы к другому животному - подземному существу, серому как крот или мышь (...). Точка перспективного схода может быть найдена под землей, и там, в подземных областях, ее трудно установить” (Подорога, 1995, с. 381). На самом деле у Кафки (подобно Гоголю) существует своеобразная - вне- и несистемная - иерархия уранического и хтонического ${ }^{3}$. В иерархии место Кафки„птицы” незаменимо ничем и оно никуда не „регрессирует”. Но в такой иерархии, с другой стороны, находится ниша также для подземного/хтонического (для „кротов” и „мышей”; ср. хтонического Вия, который „весь был в черной земле” (Гоголь, 2009-2010, т. 2, с. 448)), чем устанавливается фрагментарно-целостная и парадоксальная картина мира - по-своему присущая обоим авторам.

Согласно замечанию Подороги, основанному на письме Кафки к отцу, „быть сыном - разве это удел Кафки? В виновности отца видится спасение сына, но для этого сын должен перестать быть сыном собственного отца, перестать быть его малым двойником. (...) Кафка упорно, почти маниакально пытается свести

3 По словам Мелетинского, в творчестве Кафки „субъект и объект взаимозависимы, и эта зависимость коррелируется с дихотомией миров небесного и земного” (Мелетинский, 2001, c. 138).

4 Ср.: „Мы скажем, что для Кафки животная сущность является выходом, линией ускользания, пусть и на одном и том же месте или в клетке. Выход, а не свобода. Живая линия ускользания, а не нападение” (Делез, Гваттари, 2015, с. 45). В цитате образ „животной сущности” совсем не исключает также образа птицы. 
все имена отца к имени жестокого Бога, к вечному “Ты”, не знающему сомнений, способному уничтожить любое слабое “Я”” (Подорога, 1995, с. 406). В связи с этим („свести все имена...”) укажем на факт заведомых затруднений именования, таинственную проблематизацию самой формы имен главных героев в двух последних романах Кафки, Процесс и Замок, - Йозеф К. и К. соответственно. При этом К. - первая буква фамилии самого писателя, что выглядит не столько „автобиографично”, сколько символично, т.е. вне однозначного буквализма.

То, как Подорога оценивает романистику Кафки в целом, довольно справедливо также в отношении Вия: „Романы Кафки являются необычными оптическими устройствами и не могут стать полноценными романами [насчет степени “полноценности” - она у Кафки, безусловно, самая высокая. - С. Ш.], ибо рассказываемая история все время наталкивается на неподвижное тело героя: он в центре всех взглядов, его видят, но он сам не способен существовать без этих взглядов. Нарушена коммуникация" (Подорога, 1995, с. 394-395). Однако разве не таков и Хома под взглядами Вия и панночки в церкви (роль взгляда последней также не следует преуменьшать: он не прямо смертелен, но также ф(атален)?

Взгляд на панночку в гробу словно окончательно „влюбляет” Хому в нее и готовит его покорность перед взглядом Вия: „...он не утерпел, уходя, не взглянуть на нее и потом, ощутивши тот же трепет, взглянул еще раз. В самом деле, резкая красота усопшей казалась страшною” (Гоголь, 2009-2010, т. 2, с. 439). В отношении Вия Хома также не смог отвести взгляда: „Не вытерпел” (Гоголь, 2009-2010, т. 2, с. 448). Бурсак ожидает - не просто предчувствует, но именно почти подготавливает эти взгляды; в них для него - тайна (по принципу „смертное манит”), и под этими взглядами живя, взглянув, умирает.

Особо процитируем гоголевский пассаж, содержащий мотив весомости взгляда именно умершей панночки:

Он отворотился и хотел отойти; но по странному любопытству, по странному поперечивающему себе чувству, не оставляющему человека, особенно во время страха, он не утерпел, уходя, не взглянуть на нее и потом, ощутивши тот же трепет, взглянул еще раз. (...) Оно [лицо панночки. - С. Ш.] было живо, и философу казалось, как будто бы она глядит на него закрытыми глазами. Ему даже показалось, как будто из-под ресницы правого глаза ее покатилась слеза, и когда она остановилась на щеке, то он различил ясно, что это была капля крови.

(Гоголь, 2009-2010, т. 2, с. 439)

И далее:

Она ударила зубами в зубы и открыла мертвые глаза свои. Но не видя ничего, с бешенством - что выразило ее задрожавшее лицо - обратилась в другую сторону и, распростерши руки, обхватывала ими каждый столп и угол, стараясь поймать Хому. Наконец остановилась, погрозив пальцем, и легла в свой гроб.

(Гоголь, 2009-2010, т. 2, с. 441).

Пушкин в Анчаре (1828) задолго до философа ХХ в. Сартра (см.: Кузин, 2015) фиксирует уже в одном только взгляде индивида возможность порабощения другого. В такой трактовке взгляда Пушкиным вскрывается более радикальное и глубокое значение по сравнению с привычно констатируемой коннота- 
цией торжества деспотических институтов. Дело идет об экзистенииальном и антропологическом измерении „взгляда”-„господства”, обращающего, в том числе в глубь архаики - к мифологическому образу Медузы Горгоны. Архаика Медузы впоследствии „отзовется” также во взгляде гоголевских Вия и ведьмы-панночки.

В мотивах взгляда в Вие заметны черты художественной ситуации Анчара в качестве притчево-историальной и притчево-политической. Хотя в Вие притчевость более очевидна, чем историчность или „политичность”, две последние составляющие также косвенно заданы. Вий и панночка побеждают Хому в исторической ситуации в целом (ср. вполне конкретный антураж киевской бурсы, полуанахронический-полуисторический колорит селения панночки), их власть „политическая” (внутримировая) в таком отношении, в каком дьявол „князь мира сего”.

Однако (как в Анчаре, Вие) и землемер К. у Кафки направлен в Замок по указанию некоего властителя. Сюжет Замка и Вия сводится к тому, что протагонист призывается для осуществления определенной деятельности из одного локуса в некое другое (загадочное) место. В Вие хутор панночки - в окрестностях Киева, где школяр Хома обучается в духовной семинарии и имеет статус „философа”, соответствующий курсу обучения (хотя, конечно, само его заданное нарратором/автором положение философа превышает один только формальный статус и полностью символично). Нерв сюжета в том, что Хома вторично прибывает на хутор для заупокойных таинств над умершей, однако не завершаемых и не приводящих к позитивному результату. Хома погибает, нечисть застывает в церкви, „обмирая” в ключе почти фольклорных обмираний, считающихся посещениями „того” света (Толстая, 1995, с. 278-279.) - „обмирая” буквально, чем метафора овнешняется, превращаясь в сложный символ.

У Кафки землемер К. приглашен для соответствующих работ в некий Замок, но не может найти даже дороги к нему, проходя через череду нелепых встреч с чиновниками и рядом других лиц в окрестностях Замка, в Деревне. Сначала Замок представляется К. чем-то значительным:

Теперь весь Замок ясно вырисовывался в прозрачном воздухе, и от тонкого снежного покрова, целиком одевавшего его, все формы и линии выступали еще отчетливее. Вообще же там, на горе, снега как будто было меньше, чем тут, в деревне, где К. пробирался с не меньшим трудом, чем вчера по дороге. Тут снег подступал к самым окнам избушек, навстречу тяжело нависали с низких крыш сугробы, а там, на горе, все высилось свободно и легко - так по крайней мере казалось снизу.

(Кафка, 1991, с. 21)

Далее, однако, оценка К. Замка меняется в сторону снижения:

Но чем ближе он [К. - С. Ш.] подходил, тем больше разочаровывал его Замок, уже казавшийся просто жалким городком, чьи домишки отличались от изб только тем, что были построены из камня, да и то штукатурка на них давно отлепилась, а каменная кладка явно крошилась.

(Кафка, 1991, с. 21) 
Это изображение очень напоминает пародийно-дискредитирующее описание Кочкаревым в Женитьбе дома Агафьи Тихоновны: „Да ведь только слава, что каменный, а знали бы вы, как он выстроен: стены ведь выведены в один кирпич, а в середине всякая дрянь - мусор, щепки, стружки" (Гоголь, 2009-2010, т. 4, с. 346).

Затем у Кафки следует:

Мельком припомнил К. свой свой родной городок; он был ничуть не хуже этого так называемого Замка. (...) И К. мысленно сравнил церковную башню родного города с этой башней наверху. Та башня четкая, бестрепетно идущая кверху, с широкой кровлей, (...) вся земная (...) - но устремленная выше, чем приземистые домишки, более праздничная, чем их тусклые будни. А эта башня наверху [Замка. - С. Ш.] представляла собой однообразное круглое строение (...) с маленькими окнами, посверкивающими сейчас на солнце - в этом было что-то безумное - и с выступающим карнизом, чьи зубцы, неустойчивые, неровные и ломкие, (...) врезались в синее небо. Казалось, будто какой-то унылый жилец, которому лучше всего было бы запереться в самом дальнем углу дома, вдруг пробил крышу и высунулся наружу, чтобы показаться всему свету.

(Кафка, 1991, с. 22)

В приведенной цитате обращает на себя внимание сравнение Замка с церковью, что корреспондирует образу храма в Вие. В обоих случаях сопоставляются мотивы уранического, это: башня Замка наверху; устремленная ввысь башня церкви родного города К.

Хотя башня в родном городе и „вся земная”, этому придана позитивная коннотация, раскрываемая через корреляцию башни с вертикалью. В родной церкви К. - равновесие земного и небесного, а башня Замка дана в отсутствии подобного равновесия и вообе в невнятице относительно статусов и состояний „земного” и „небесного”, сниженно.

В последующем Кафка пытается, однако, несколько приподнять наполнение образа Замка за счет противопоставления ему „абсурдной” Деревни, но проведенное им сравнение объективно умаляет оба локуса: „... перерождаются - становятся дикой, беспардонной оравой, для которой уже не существует законов, а только их ненасытные потребности" (Кафка, 1991, с. 199).

Имя Замка здесь употреблено все же в качестве иллюзорного идеала: высокий статус Замка ничем не подтвержден, за ним - только пустая надежда. Сущность самого Замка на деле едва ли лучше того, что К. видит в Деревне, ведь

5 По не вполне точным наблюдениям Подороги, „еще более поразительны изменяющиеся глубины и профили пространств, которые накатываются на героя [Кафки. - С. Ш.] внезапно, с самой неожиданной стороны, и он не столько находит путь к ним (хотя и ищет его), сколько попадает в них. Чердаки, чуланы, маленькие комнаты, клетки или коридоры, даже открытые пространства наспех приделаны друг к другу и никаким образом не соотносимы с какимлибо единым пространством, в котором они могли бы получить свое определенное место и смысл. (...) Господин К. (во всех его романных и новеллистических масках) ведет себя как типичная сомнамбула, чье движение (...) полностью определяется глазными траекториями инстанции великого надзора - Страха” (Подорога, 1995, с. 395). Однако у Кафки все же задана модель „единого” пространства (через первоначальные образы Замка, через воспоминание К. об архитектуре родного города и т.п.), есть у него и уранические образы пространства. 
именно благодаря попустительству Замка (его владельца? При всех ссылках на владельца его роль как субъекта действия неясна) возможна „дикая, беспардонная орава” Деревни. Нарратору/автору лишь хотелось бы надеяться, что идеал есть, сохранился, отсюда ламентация по поводу Замка, чья прошлая - видимо, считающаяся славной - история по инериии призвана „вдохновлять”.

По поводу соотношения Замка и Деревни Иваницкий точно заметил: „Деревня же, в которой останавливается землемер, есть тень Замка, то есть “псевдопространство”' (Иваницкий, 2000, с. 157). Но в качестве „тени” Деревня обличает самый Замок.

Различные исследователи видели в символике Замка то сверхъестественно позитивное, то сверхъестественно негативное. Брод, например, считал, что образ Замка воплощает благое начало, Бога, а землемер К. - отступник, не слышащий призывов свыше (Брод 2000a, 2000b, 2003)6. Трудно принять такую оценку. Замок ускользает не только из-за индифферентности или поливалентности образа К. Подобно Хоме, К. воплощает в себе черты и снижающие, и возвышающие, а то и вовсе неопределенные (как сказано в первом томе Mертвых душ о Манилове: „Ни в городе Богдан, ни в селе Селифан” (Гоголь, 2009-2010, т. 5, с. 24)).

В описании гоголевского хутора тоже фигурирует перспектива горы, как потом у Кафки (и тоже в туманно-символическом ореоле; Деревня Кафки может служить некоей параллелью к гоголевскому хутору):

Все селение помещалось на широком и ровном уступе горы. С северной стороны все заслоняла крутая гора и подошвою своею оканчивалась у самого двора. При взгляде на нее снизу она казалась еще круче, и на высокой верхушке ее торчали кое-где неправильные стебли тощего бурьяна и чернели на светлом небе. (...) С вершины вилась по всей горе дорога и, опустившись, шла мимо двора в селенье. Когда философ измерил страшную круть ее и вспомнил вчерашнее путешествие, то решил, что или у пана были слишком умные лошади, или у козаков слишком крепкие головы, когда и в хмельном чаду умели не полететь вверх ногами вместе с неизмеримой брикою и багажом. (...) С правой стороны этих лугов тянулись горы...

(Кафка, 1991, с. 429-430)

Отдельным хронотопическим планом выступает в Вие хуторская церковь. В ней умершей дается сила временно оживать и даже летать в своем гробу, туда она зазывает другую нечисть. Этот мотив подготовлен уже первоначальным описанием церкви: „Церковь деревянная, почерневшая, убранная зеленым мохом, с тремя конусообразными банями, уныло стояла почти на краю села. Заметно было, что в ней давно уже не отправлялось никакого служения" (Гоголь, 2009-2010, с. 433-434).

Фатальная ошибка Хомы в восприятии ведьмы - переход из школярского карнавализованно-мениппейного регистра смысла в буквализированно-инфернализированный регистр. Эта ошибка приводит героя к гибели. Церковь же остается наполненной застывшими в ней монстрами, а в итоге вообще оказывается заброшенной:

6 Негативна же оценка образа Замка у А. Гулыги (см. далее). 
Раздался петуший крик. Это был уже второй крик; первый прослышали гномы. Испуганные духи бросились, кто как попало, в окна и двери, чтобы поскорее вылететь, но не тутто было: так и остались они там, завязнувши в дверях и окнах. (...) Так навеки и осталась церковь, с завязнувшими в дверях и окнах чудовищами, обросла лесом, корнями, бурьяном, диким терновником, и никто не найдет теперь к ней дороги.

(Гоголь, 2009-2010, с. 449)

В первой редакции Вия (1835) об итоговой заброшенности церкви говорилось еще резче: „Церковь поросла мхом, обшилась лесом, пустившим корни по стенам ее; никто не входил туда и не знает, где и в какой стороне она находится" (Гоголь, цит. по: Виноградов, Воропаев, 2009, с. 649).

Учитывая, что хутор заведомо мал, трудно представить, можно ли „не найти дороги” к церкви, к тому же, судя по описанию нарратора/автора, единственной в этом селении. А „не знать”, „где и в какой стороне” она, тем более знаменует внедрение в общий хронотоп Вия не просто пространственной неразберихи, а десакрализации самих внутримировых институций.

Высказывалось мнение, что в Вие изображена униатская церковь (Виноградов, Воропаев, 2009, с. 646-656): с точки зрения комментаторов, такой факт способен оправдать попущение на бесчинства внутри ее хронотопа, усилить аспект ее „чуждости”. Однако здесь нужно заметить, что отношение Гоголя к католицизму в главном не являлось негативным.

Кафковский Замок словно претендует на права (статус) церкви, подменяя сакральное светским или, точнее, делая из светского паллиатив сакрального. Это также входит в общий кафковский контекст десакрализации. Кроме того, кафковская Австро-Венгрия - католическая страна, что косвенно соотносится с возможной „униатскостью” церкви в Вие („униатскостью”, не являющейся у Гоголя отрицательным маркером).

Налицо повышенное внимание обоих авторов к пространственно-временной организации художественного мира, к неоднородности, „скольжению”, „вязкости” хронотопических миров и планов. К., несмотря на все свои старания, не может попасть в Замок:

Он снова зашагал вперед, но дорога была длинно. Оказалось, что улица - главная улица Деревни - вела не к замковой горе, а только приближалась к ней, но потом, словно нарочно, сворачивала вбок и. не удаляясь от Замка, все же к нему и не приближалась. К. все время ждал, что наконец дорога повернет к Замку, и только из-за этого шел дальше.

(Кафка, 1991, с. 23-24)

Характерно описание попытки бегства Хомы с хутора после второй ночи, проведенной в церкви:

И Хома положил непременно бежать. (...) Философ со страхом и дрожью отправился потихоньку в панский сад, откуда ему казалось удобнее и незаметнее было бежать в поле. (...). За плетнем, служившим границею сада, шел целый лес бурьяна, в который, казалось, никто не любопытствовал заглядывать (...). Когда философ хотел перешагнуть плетень, зубы его стучали и сердце так сильно билось, что он сам испугался. Пола его длинной хламиды, казалось, прилипала к земле, как будто ее кто приколотил гвоздем. Когда он переступал плетень, ему казалось с оглушительным свистом трещал в уши какой-то го- 
лос: „Куда, куда?“. Философ юркнул в бурьян и пустился бежать, беспрестанно оступаясь о старые корни и давя ногами своими кротов.

(Гоголь, 2009-2010, с. 445-446)

И далее:

Он видел, что ему, выбравшись из бурьяна, стоило перебежать поле, за которым чернел густой терновник, где он считал себя безопасным, и, пройдя который, он по предположению своему думал встретить дорогу прямо в Киев. Поле он перебежал вдруг и очутился в густом терновнике. Сквозь терновник он пролез, оставив, вместо пошлины, куски своего сюртука на каждом остром шипе, и очутился на небольшой лощине. (...) Небольшой источник сверкал чистый, как серебро. (...)

- Нет, лучше побежим вперед: неравно будет погоня!

Эти слова раздались у него над ушами. Он оглянулся: перед ним стоял Явтух. (...)

- Напрасно дал ты такой крюк, - продолжал Явтух, - гораздо лучше выбрать ту дорогу, по какой шел я: прямо мимо конюшни.

(Гоголь, 2009-2010, с. 446)

Вокруг хутора гоголевской панночки - в виде продолжения его кажущейся идиллии - некие „заповедные места”, привлекающие внимание Хомы, на миг взлелеявшего мечту поохотиться там. Однако ситуация заметно осложняется тем, что в Вие наличествует еще один хронотопический центр - киевская бурса, сам Киев. Бурса - топос карнавальности, „антиповедения”. Номинально предполагаемый „сакральный” смысл бурсы (духовного учебного заведения) в начале повести карнавально редуцирован и даже по-доброму шаржирован. Во „второй части” повести, когда Хома призывается в качестве бурсака (будущего духовного лица) для заупокойных бдений и ожидается, казалось бы, некое раскрытие „сакральности”, та отказывает в проявлении: Хома погибает.

Известная „игра” Кафки с художественным пространством, когда оно предстает неравномерным, не равным себе, словно меняет собственные параметры - аргумент в пользу „фантастичности” мира Замка. Исследователи не раз обращали внимание на разнопорядковость хронотопических планов в Bue: разные персонажи-наблюдатели замечают в художественной реальности повести разное, причем оценка одного и того же хронотопического вида часто разнится.

К Вию и Замку вполне относимы интересные замечания Фарино о пространстве в Мертвых душах (Фарино, 1979). Исследователь отметил в нем высокую степень аморфности (извилистость, запутанность дорог, обилие поворотов); необыкновенную растяжимость, безразмерность. В последнем случае, согласно Фарино, пространство получает вид безмерного мира, к которому неприложимы ни категории направления, ни категории расстояния, ни даже категория непрерывности.

По поводу отсутствия категории направления в Мертвых душах с Фарино нельзя согласиться, т.к. автор/нарратор, по верному наблюдению Лотмана, стремится превратить ненаправленное движение Чичикова - в направленное, причем в лучшую сторону (Лотман, 1988). У Хомы и К. задан такой же вектор, но он не реализуется в рамках сюжета. 
Герой Кафки, а с ним читатель, становятся свидетелями общемирового экзистенциального абсурда, но как его истолковывать? Важен вопрос о том, для кого именно (с какой позиции предпонимания) наблюдаемое абсурдно: для какой группы героев, читателей, для какого измерения „образа автора”? Иначе говоря, „абсурд” историчен: имеет свои рамки и границы.

По мнению Набокова, „у Гоголя и Кафки абсурдный герой обитает в абсурдном мире, но трогательно и трагически бьется, пытаясь выбраться из него в мир человеческих существ - и умирает в отчаянии" (Набоков, 1998, с. 329). Однако необходимо признать, что сам герой Гоголя и Кафки - вне абсурда. Если бы дело обстояло иначе, между героем и миром отсутствовало бы всякое различие. Напомним принципиальное замечание Камю о том, что абсурд не находится ни в мире, ни в сознании человека, а рождается из их сопоставления (Камю, 1990).

Михайловым показано, что история „характера” (в широком значении термина) от античности к Новому и новейшему времени развивалась в переносе мотивации поступков героя с внешнего (боги, мировые силы, мир и т.д.) на внутреннее, т.е. на переживания и действия самого персонажа (Михайлов, 1997). У Гоголя и Кафки - известное равновесие „внешнего” и „внутреннего”. Мир (мировые силы) и герой вполне уравнены в правах. В Вие и в целом у Кафки мир и герой вступают в противоборство в отстаивании своей (у каждого) „правды”.

Имя владельца кафковского Замка символично: граф Вествест, т.е. „Западзапад” в дословном переводе с английского, чем подчеркивается пристальное внимание Кафки к исторической судьбе Запада, судьбе европейского человечества в целом. Английское написание „West” почти совпадает с немецким обозначением Запада „Westen”. Кафке вместо немецкого слова понадобилось прибегнуть к английскому, чтобы несколько полнее „охватить” в образе имени владельца Замка весь Запад. Вместе с тем „West” (как часть корня фамилии „Вествест”) допустимо воспринимать просто как усеченное „Westen”.

Кроме того, это именование ее владельца объяснимо онтологически-мистическими каламбурами, риторически-пародийными (т.е. самосознающимися, но и самосознающими, при этом в карнавализованно-мениппейном отталкивании от „официальной” риторики).

Наконец, потенциальное скрещение разноязычных лексем в имени Вествест напоминает (онтологизированную) „языковую игру” - в предвосхищении Витгенштейна, начавшего свою философскую деятельность еще при жизни Кафки, также в Австро-Венгрии. Неканоническая, парадоксальная „логика” Витгенштейна с ее акцентом на языковом обозначении и собственно языковом сознании соотносима с манерой Кафки.

Графский титул Вествеста так или иначе отсылает к идее старой аристократии Запада как „хранительницы” „славного” прошлого западной культуры и вообще западного образа жизни, как представителя общих „консервативно-патриархальных” устоев (но представителя виртуально-иронически, не реально). С другой стороны, некие надежды нарратора/автора на достоинства „графа”хозяина способны вызвать косвенную ассоциацию с графом Толстым, чья фигура и творчество вызывали у Кафки глубокое уважение. Поздний Толстой стремился отказаться от собственности, от имения, что созвучно фактическо- 
му неучастию Вествеста в делах кафковской Деревни ${ }^{7}$ или же способно рассматриваться в качестве фигурального выражения надежды Кафки на внедрение „толстовских” принципов в дела управления Замком и Деревней - в качестве моделей уже не только узко Запада, а всей Европы.

С возможной аллюзией на личность графа Толстого в персоним „граф Вествест” входит образ России, о притягательной силе которой Кафка писал в своих дневниках. Символическое расширение модели Запада до общеевропейского хронотопа трудно отрицать. С образом России в реальность Замка включаются и неизбежные аллюзии на Гоголя, также ценимого Кафкой.

Кафка в момент создания Замка уже мог познакомиться с историософским трудом Шпенглера Закат Европь, где отражена идея угасания западной культуры, ее „перерождения” в механистическую цивилизацию (Шпенглер, 1918, т. 1). Метафизика Замка отчасти близка шпенглеровским идеям. Гоголь их в чем-то предвосхитил в своей критике цивилизации Нового времени, в своих оценках современной ему Европы (см. особенно отрывок Рим).

В связи с общеевропейским контекстом/подтекстом историософии Замка уместно привести замечания Гоголя о Западной Европе из черновика его неотправленного письма Белинскому (конец июля - начало августа 1847 г.):

Вы говорите, что спасенье России в европейской цивилизации. Но какое это беспредельное и безграничное слово. Хоть бы вы определили, что такое нужно разуметь под именем европейской цивили(зации), которое бессмысленно повторяют все. Тут и фаланстерьен, и красный, и всякий, и все друг друга готовы съесть, и все носят такие разрушающие, такие уничтожающие начала, что уже даже трепещет в Европе всякая мыслящая голова и спрашивает невольно, где наша цивилизация? И стала европейская цивилизация призрак, который точно (никто) покуда не видел, и ежели (пытались ее) хватать руками, она рассы(пается). И прогресс, он тоже был, пока о нем не дум(али, когда же?) стали ловить его, он и рассыпал(ся).

(Гоголь, 2009-2010, т. 14, с. 386).

Для Гоголя Европа - „беспредельное и безграничное слово”, что уже само по себе свидетельствует о крайней сложности этого концепта в гоголевском восприятии, об отсутствии у Гоголя плоского критицизма в отношении европейского мира. Фраза И стала европейская иивилизаиия призрак также вовсе не развенчивает Запад, но ставит перед его загадкой, перед поиском ее оснований. Ведь и русская жизнь для Гоголя - загадка, „тайна”. Обе загадки не могут дать, в понимании Гоголя, прямого ответа. Вопрос Гоголя к Руси „(...) куда ж несешься ты?”, (Гоголь, 2009-2010, т. 5, с. 239) имплицитно подразумевает сходный косвенный вопрос также к „посторанивающимся и дающим ей дорогу” „другим народам и государствам” (Гоголь, 2009-2010, т. 5. 239). Оба вопроса остаются в первом томе без ответа.

В Вьбранных местах из переписки с друзьями Гоголь предлагает в целом позитивную оценку заданному Петром I в России „чистилищу просвещенья европейского", замечая, впрочем:

7 По поводу отношения Кафки к позднему Толстому см., напр.: Müller, 1992; Шульц, 2018. 
По мне, безумна и мысль ввести какое-нибудь нововведенье в Россию, минуя нашу Церковь, не испросив у нее на то благословенья. Нелепо даже и к мыслям нашим прививать какие бы то ни было европейские идеи, покуда не окрестит их она светом Христовым.

(Гоголь, 2009-2010, т. 6, с. 73)

Здесь возможность „привития европейских идей” в России вовсе не отрицается, но ставится в зависимость от их адаптации православием, т.е. адаптации религиозной. Религиозные вопросы занимают важное место и в творчестве Кафки, и он также склонен через них оценивать смысл того или иного явления ${ }^{8}$. Религиозная оптика рассмотрения вполне светских вопросов сближает Кафку и Гоголя.

Непосредственно в Вие исторический/историософский контекст задан через образы Киева, бурсы и Братского монастыря. У Гоголя исторические детали по сравнению с Кафкой, конечно, конкретнее. Братский монастырь упоминался еще в Страшной мести, что свидетельствует об особом интересе Гоголя к этому локусу. Согласно справке Виноградова и Воропаева, точное название монастыря - Киево-Братский, „основан в 1588 г. при Богоявленской церкви на Подоле; в 1615 г. перешел в ведение Киевского братства (отсюда и название). В XVII в. монастырь стал одним из центров борьбы за Православие против католицизма и унии. В 1615 г. при нем открыта Киевская братская школа (в 1701-1817 гг. Киевская академия), одно время (конец XVII - начало XVIII в.) монастырь был в руках униатов" (Виноградов, Воропаев, 2009, с. 564).

Вопросы веры, понятые в том числе исторически, занимают в Вие немаловажное место, как и в Замке. Непрямо в описаниях целостного киевского хронотопа затронуты отношения православия и католицизма, поскольку какой-то период монастырь (при котором бурса) принадлежал униатам; непосредственно вопрос об этих отношениях поднят в предшествующей Вию в цикле Миргород повести Тарас Бульба.

Гоголь никогда не мог бы - вслед за Кантом - употребить термин „историческое христианство”, но он понимал, что само христианство исторично в разных значениях последнего термина, т.е. укоренено в историческом движении и несет в себе исторический смысл. И поэтому, в частности, Гоголь почти всегда воспринимал католицизм с уважением. В этом отличие Гоголя от Достоевского (Достоевский, 1983, т. 25, с. 58), противопоставившего в Дневнике писателя точку зрения „нравственную” (христианскую) и точку зрения „Историческую”. Достоевский, конечно, не отказывал христианству в историзме, как может отсюда показаться, но сам он смотрел на него словно внеисторически.

Весь хронотоп Киева (включая бурсу в качестве его части), а также Вия в целом, у Гоголя карнавализован. Философия карнавала, описанная Бахтиным, исторична, т.к. она направлена на „приручение”, позитивную „адаптацию” истории, выявление в ней смыслов обновления и смены, что, вопреки мнению Тамарченко ${ }^{9}$, совсем не противостоит христианским коннотациям и вообще христианским ценностям (Тамарченко, 2011, с. 309).

\footnotetext{
8 Об этом много писали Брод, Беньямин.

9 О констатации внутренней близости карнавальной теории Бахтина христианству см.: Coates, 1998.
} 
В произведениях Гоголя и Кафки налицо момент определенного посвятительного обряда, инициального сюжета, предполагающего испытания и временную „смерть”: Хома не выдерживает „инициации”, с землемером К. - ввиду неоконченности романа - картина менее ясна. Мелетинским ее контуры очерчены так: „...он [К. - С.Ш.] (...) ничего не добивается, засыпает в неподходящий момент, когда, кажется, мог чего-то достигнуть” (Мелетинский, 2001, с. 140). Однако такой подход делает К. „виновным” в непопадании в искомый Замок, что все же деформирует кафковские смыслы.

Более взвешенны оценки на этот счет у Камю и Бланшо. Согласно мнению Камю о Кафке: „Нужно истребить земную надежду, лишь тогда возможно спастись надеждой истинной” (Камю, 1990, с. 373.). Хотя „спасение” и „надежда истинная” в данном случае не вполне подразумевают божественную реальность (а для Кафки-мыслителя та была актуальна), Камю все же отдаленно имеет в виду их секуляризированные проекции. Далее у Камю: „Но не следует искать объяснения для каждой детали в книгах Кафки. Символ - всегда обобщение, и художник переводит его, не разрушая его цельности" (Камю, 1990, с. 361-362).

М. Бланшо пишет ${ }^{10}$ :

К. чувствует, что все, находящееся вне его, - то есть сам он, спроектированный вовне, есть не более, чем образ. Он знает, что образам нельзя доверять и что к ним нельзя привязываться. Он обладает безмерной силой сопротивления, которая подобна лишь его безмерному влечению к одной единственной точке, лишенной определенности. (...) почему тогда в этом нетерпении он обвиняется как в грехе (...)?

(Бланшо, 1998, с. 142)

Как и положено в обряде инициации, к К. приставляются „помощники”, роль которых крайне карнавализована и которые отличаются „антиповедением”, выступая „антипомощниками”, что совершенно по-мениппейному:

Как только все ушли, К. сказал помощникам: „Вон отсюда!” Ошеломленные этим неожиданным приказом, они послушались, но, когда К. запер за ними дверь, они стали рваться назад, взвизгивать и стучать в дверь. „Вы уволены” - крикнул К. - Больше я вас к себе на службу не возьму", Но они никак не унимались и барабанили в дверь руками и ногами.

(Кафка, 1991, с. 126-127)

По поводу фигур кафковских „помощников” точно выразился Беньямин:

У Кафки сирены молчат. Возможно, они молчат еще и потому, что музыка и пение у него являются выражением или по меньшей мере залогом избавления. Залогом надежды, брошенным нам из того мелкого, недовершенного и вместе с тем будничного, утешительного и вместе с тем дурацкого межеумочного мирка, где обосновались, как у себя дома, помощ-

10 Ссылки в самом тексте здесь и далее. Важно также следующее замечание Бланшо: „Смерть К. кажется необходимой развязкой для всей этой последовательности событий, через которые нетерпение гонит его до истощения его сил. В этом смысле усталость, от которой глубоко страдал и сам Кафка, - усталость и охлаждение души не меньше, чем тела, - это одно из орудий интриги, а точнее одно из измерений того пространства, в котором живет герой Замка, - в местности, где ему лишь дано блуждать вдали от всякой возможности истинного покоя" (Бланшо, 1998, с. 143). 
ники. Кафка - как тот паренек, что отправился страха искать”.

(Беньямин, 2000, с. 58-59)

Далее Беньямин косвенно сравнивает „неутомимых помощников из Замка” с фигурами дураков, что закономерно (Беньямин, 2000, с. 89). У Хомы на хуторе в период его второго появления тоже есть „помощники” - три казака, но на деле они только соглядатаи испытания, не дающие Хоме скрыться и потворствующие его гибели. Три казака - тоже „антипомощники”, почти „дураки”, усиливающие карнавально-мениппейные мотивы Вия, но в данном случае в мрачном регистре, соединяя их с трагедийными.

С карнавальностью в Вий и в Замок входят подразумеваемые акценты преодоления недолжного в истории, метафизическо-идеалистического снятия ряда исторических эпизодов из прошлого, их нейтрализации. Согласно идее средневекового философа Дамиани, Бог может отменить прошлое; она вполне могла стать одной из основ философии карнавала. К таким „недолжным аспектам” исторического относимо, что продемонстрировал Жирар, само инфернальное начало и отношение человека к нему (Жирар, 2010).

Гоголь карнавально обыгрывает инфернальные мотивы Вия, показывая их относительность - при всей их „страшности”. У Кафки инфернальность несколько снята (не буквальна). Сама абсурдность становится у Кафки превращенной формой инфернальности. Жирар во второй половине ХХ в. показал ограниченность инфернального в том плане прежде всего, что мы сами должны отказаться от „охоты на ведьм”: тогда все „ведьмы” и исчезнут.

Кафка сложно балансирует между самыми разными толкованиями сюжетной ситуации, уже „вставленными” имманентно внутрь нее. Нет сомнений, что Кафка не только символически или эмблематически, но и буквально фиксирует десакрализацию и лишение смысла, в современных ему исторических условиях, всех мифологических, религиозных, политических, общественных и иных казавшихся устоявшимися институций наличной реальности, мыслившимися до того (еще непосредственно до эпохи Кафки) фундаментом индивидуального и коллективного существования человека в мире.

Мелетинским верно замечено, что кафковская „прозаизация не ослабляет представления о могуществе высших институций. Наоборот, она подчеркивает ее таинственную силу, которая скрыта в темных углах обыденной жизни, Она вскрывает демонизм самых банальных мест и ничтожных людей” (Мелетинский, 2001, с. 137-138). Иначе говоря, при всей десакрализации, наличные институции сохраняют свою колоссальную власть, „таинственность” которой связана, впрочем, почти исключительно с субъективными намерениями автора/нарратора хотя бы как-то понять эти институции (несколько „приподнять”) и даже в чем-то извинить (sic!). В желании извинить - а не уличить - и весь пафос кафковского письма отцу. Такая позиция тесно сцеплена с кафковским отказом от „рессентимента”, от „недобрых чувств” в себе.

Землемерие - архаический в истоках вид деятельности, оно соотнесено с ритуально-мифологическими параметрами всех социальных практик, с „магическим" обустройством мира и в мире. Социальный порядок в архаике прирав- 
нивается к „космическому”. Вынужденное невыполнение землемером К. своих функций - симптом космической дисгармонии, расшатывания мироздания. Замок не оказывает герою никакой реальной помощи, хотя именно замок призвал К. для осуществления работ. В связи с ритуально-мифологическими корнями землемерия и конкретно образа землемера К. выразительна фигура гоголевского школяра Хомы, призываемого для совершения культовых отправлений итожимых негативным результатом, как и у К. Осознание переклички заданных необходимыми действий Хомы и К. проступает в свете историальной интерпретации мифологии и Откровения Шеллингом, увидевшем закономерное эволюционное движение от архаических видов мифа к Откровению и христианской мифологии.

В эпоху Кафки возвышенный статус землемерия уже почти не осознавался, благодаря чему образ землемера К. (именно в качестве землемера) несколько снижен $^{11}$. С другой стороны, согласно точному замечанию Беньямина,

Эпоха, в которую Кафка живет, не знаменует для него прогресса по отношению к праистокам. Действие его романов разыгрывается в мире первобытных болот. Тварь живая явлена у него на той стадии, которую Бахофен называет гетерической. А то, что стадия эта давно забыта, вовсе не означает, что она не вклинивается в наш сегодняшний день. Скорее напротив: именно благодаря забвению она и присутствует в нашей современности.

(Беньямин, 2000, с. 79-80)

Поздний Гуссерль в Началах геометрии (1936) увидел исток геометрии („образца” науки) именно в землемерии как, в данном случае, жизненной практике, обращенной непосредственно к „жизненному миру” в его „допредикативности” (дотеоретичности, неотвлеченности (Гуссерль, 1996. с. 210-245)). Возвращение к „жизненному миру” в его историчности Гуссерль объявляет целью забывших о своих истоках современных ему наук; исток искусств тоже возводим к исторически понятому „жизненному миру”, подобно истоку самого „жительствования человека" (Хайдеггер).

Хотя концепция Гуссерля возникла уже после смерти Кафки, заметны переклички между идеями искомых для двух авторов оснований жизни, наук, художества. Эти основания констатируются Кафкой и Гуссерлем в качестве утраченных и долженствующих вновь стать обретенными. Вместе с тем, при всем интересе Кафки к архаике, он - не за простую реанимацию архаики. Мысль Кафки (как, впрочем, и Гуссерля) гораздо сложнее и в любом случае обращена по преимуществу в будущее, а не в прошлое. Поэтому у обоих дело идет не о реанимации чего-то из прошедшего, а о движении вперед с оглядкой на позитивные элементы опыта истории.

11 Любопытно, что в романе Теккерея Виргинцы бегло мелькает образ землемера, причем в сниженной плоскости, хотя под ним имеется в виду будущий герой борьбы за независимость США Вашингтон: „Неужели представительница рода маркизов Эсмондов выйдет замуж за младшего отпрыска колониальной семьи, которого к тому же предназначали в землемеры!” (Теккерей, 1991, т. 1, с. 95). Кафка, видимо, учитывал подобные то снижающие, то возвышающие коннотации при создании собственного образа землемера. 
Если ранний Гуссерль с его концепцией интендирующей роли сознания сближается с солипсизмом, т.е. с идеей „построения” внешнего мира исходя из данных одного лишь сознания субъекта, то поздний Гуссерль практически полностью преодолевает солипсизм за счет непосредственного обращения к самому миру (а не сознающему субъекту) (Хабермас, 2008, с. 160).

Кафка мог знать ранние гуссерлевские сочинения: философия тесно входила в круг его чтения. Его Карл Россман (Америка), Йозеф К. (Процесс) и К. живут в мире, словно определяемом солипсичными другими: в Америке Карл - игрушка в руках проходимцев; в Процессе герой без вины осуждается; в Замке протагонист полностью зависим от сил, приближенных к Замку и сил самого Замка. В условиях художественной реальности Замка К. сам в чем-то становится „солипсистом”, по-своему задавая и моделируя горизонт мира. Но Кафка всегда пытался найти путь к объективности, к реальности жизненного мира (предвосхищая, в частности, позднего Гуссерля). Путь к реальному „жизненному миру”, несомненно, ищет и К.

Гоголь строил собственные художественные миры на скрещении различных точек зрения своих героев на события, отдавая должное их свободе воли ${ }^{12}$. Смирнова-Россет сохранила ценное высказывание Гоголя о том, что Боссюэ в своей Всеобщей истории (XVII в.) будто бы лишает человека свободы: „...с духовной стороны в ней не видна свобода человека, которому Создатель предоставил действовать хорошо или дурно” (Смирнова-Россет, 1990, с. 450-451). В мире самого Гоголя идея свободы воли могла доходить до констатации доли „солипсизма” (излишнего субъективизма, если в более мягкой формулировке) в действиях его героев, что обнаруживается, к примеру, в поведении инфернальных сил или приравненных к ним - таков, например, Чичиков-„черт” в восприятии Мережковского (1991, с. 213-309). В Вие это - злоупотребляющая магией „солипсистка" панночка (отвергающая божественный миропорядок) и ее демонические то ли хозяева, то ли подчиненные (см. далее).

Ощутимо сходство во внутреннем облике протагонистов Гоголя и Кафки: это некий вполне обычный человек, не плохой и не хороший („эвримэн”), от которого, однако, ожидается степень соответствия некоему испытанию-смыслу (испытанию-„бессмыслице”). У героев обоих писателей необходимо различать существование и сущность. На уровне своего существования герои не выдерживают испытания - соответственно инфернальностью у Гоголя, и, у Кафки, абсурдом как исторически новым типом значения, абсурдом в качестве почти тотальной десакрализации.

Последняя - не только результат „снятия с мира чар” (устранения идеи Бога), но результат перетолкования, пересоздания „старых” чар в иные (небожественные). „Сакральное” вообще - может быть и „демоническим”, т.к. „духовное” способно существовать и с отрицательным знаком (ср. падших ангелов). Лосев

\footnotetext{
12 Меерсон справедливо показала, что разные точки зрения в том или ином произведении составляют целые „персонологии”, т.е. значимы в качестве различных ключей толкования ситуаций художественных миров (что развивает подходы Бахтина к диалогу и полифонии), см.: Меерсон, 2009.
} 
показал, что без „чар”, т.е. без мифа и мифологии, широко понятых, никто не может обойтись, включая богоборцев и атеистов (Лосев, 1994). В недавней книге Зенкина о „небожественном сакральном” почти не уделено внимания именно демоническому „сакральному” (ср.: Зенкин, 2012).

Когда отец панночки беседует с Хомой перед его бдениями, то выражает уверенность в факте предсмертного желания дочери о спасении ее души, искренней ее заботы об этом:

- Если бы только минуточкой долее прожила ты, - грустно сказал сотник, - „то верно бы я узнал все. „Никому не давай читать по мне, но пошли, тату, сей же час в киевскую семинарию и привези бурсака Хому Брута. Пусть три ночи молится по грешной душе моей. Он знает...“ А что такое знает, я уже не услышал. (...) Ты, добрый человек, верно, известен святою жизнию своею и богоугодными делами, и она, может быть, наслышалась о тебе.

(Гоголь, 2009-2010, с. 431)

Ольга в Замке столь же похвально будет отзываться о К., но не в плоскости сакрального, а в аспекте практически целиком десакрализованной социальности своего настоящего (на основе интриг, нравов Замка и Деревни, якобы успешного лавирования героя между ними):

Ты имеешь право заходить в Замок, ты постоянный посетитель канцелярий, проводишь целые дни в одном помещении с Кламмом, тебя официально считают посыльным, ты рассчитываешь получить форменное платье, тебе поручают передачу важных документов, - вот кто ты такой, вот что тебе разрешено, а ты приходишь домой, и, вместо того чтобы нам с тобою обняться, плача от счастья, (...) во всем ты сомневаешься...

(Кафка, 1991, с. 165)

Сотник надеется, что последующие действия Хомы поспособствуют осуществлению „желания” дочери, отец готов всячески поддержать ее устремления, как он их понял. Сталкиваемся ли мы здесь с неискушенной наивностью отца относительно посмертных ожиданий панночки (и его незнанием о ее „ведьмовстве”) или, в самом деле, имела место некая серьезная предсмертная ее надежда? Вопрос не надуманный. Во втором случае Хома словно „призван”, а инфернальные превращения живой и мертвой красавицы объяснимы, может быть, каким-то идущим из прошлого страшным заклятием, под которое та подпала, будучи не в состоянии сразу избавиться от него ${ }^{13}$. Наконец панночка способна, в зависимости от ситуации, выбрать путь промежуточного скольжения между противоположными силами, мирами и смыслами, когда она все решает и решает, к какому стану примкнуть в конечном счете.

Бдения в хуторской церкви - поединок инфернальности и богоугодности. Панночка могла задумать подобную двусмысленность: если победит Хома, то спасу свою душу вместе с его победой (ее „привязанность” к нему очевидна);

13 Вопрос о панночке как о „жертве” темных сил и об искренности ее „желания” спасти душу рассматривал также Бочаров (2007a, 2007b). Необходимо также отметить излишне буквалистскую и психологистическую трактовку Бочаровым сцены полета Хомы с ведьмой: тем самым сцена лишается символического и условного значения. 
если же он посрамится - отыграюсь за свою физическую смерть и доставлю радость силам ада („начальнику гномов” и т.п.)

Отцу сотнику ничего неизвестно об инфернальности дочери. С другой стороны, то, что церковь с самого начала действия оказывается заброшенной (хотя и не в такой степени, как в финале повести), свидетельствует об индифферентности сотника в отношении к религии и к благочестию. Лишь ради дочери - уже умершей - сотник вспоминает о храме:

Сотник сам шел впереди, неся рукою правую сторону тесного дома умершей. Церковь деревянная, почерневшая, убранная зеленым мохом, с тремя конусообразными банями, уныло стояла почти на краю села. Заметно было, что в ней давно уже не отправлялось никакого служения.

(Гоголь, 2009-2010, с. 433-434)

Сотник готов вынашивать даже планы жестокой мести убийце дочери, которого он видит перед собой, но не может опознать:

- Я не о том жалею, моя наймилейшая мне дочь, что ты во цвете лет своих, не дожив положенного века, на печаль и горесть мне оставила землю. Я о том жалею, моя голубонька, что не знаю того, кто был, лютый враг мой, причиною твоей смерти. И если бы я знал, кто мог подумать только оскорбить тебя, или хоть бы сказал что-нибудь неприятное о тебе, то, клянусь богом, не увидел бы он больше своих детей, если только он так же стар, как и я; ни своего отца и матери, если только он еще на поре лет, и тело его было бы выброшено на съедение птицам и зверям степным. Но горе мне, моя полевая нагидочка, моя перепеличка, моя ясочка, что проживу я остальной век свой без потехи, утирая полою дробные слезы, текущие из старых очей моих, тогда как враг мой будет веселиться и втайне посмеиваться над хилым старцем (...).

Философ был тронут такою безутешной печалью. Он закашлял и издал глухое кректание, желая очистить им немного свой голос.

(Гоголь, 2009-2010, с. 432-433).

Другой ненадуманный вопрос: панночка по отношению к Вию - подчиненная или хозяйка? Обычные представления о ведьме диктуют, казалось бы, однозначно первый вариант ответа, но в гоголевской ведьме заметны черты мифофольклорной (дохристианской, языческой) „хозяйки леса”, „хозяйки зверей” (ср. мотив лая при приближении компании школяров к хутору; вообще мотивы лая в повести), наконец матриархального архетипа „Великой матери”, негативно переосмысленного в эпоху патриархата (Шульц, 2017).

Отсутствие имени у панночки (хотя отец или дворня могли бы его упомянуть) делает ее образ тем более загадочным и амбивалентным. В своей потенциальной полноте образ панночки несводим ни к „ведьме”, ни к просто „красавице": он многосмыслен, что зависит также от субъективизированных точек зрения других персонажей. Для большинства обитателей хутора панночка ведьма, но их мнения поданы автором/нарратором объектно-комически, т.е. не всегда способны вызывать доверие. Афоризм одного из героев повести - „все бабы, которые сидят на базаре, - все ведьмы” (Гоголь, 2009-2010, с. 450) - не только метафоризирует образ колдуньи, но и карнавализирует его, делает неопасным. 
Несмотря на признаки снижения образа Хомы, в нем - через акцент на его сущности как „философа” (жреца, поэта в архаическо-романтическом понимании) и будущего священнослужителя - заметно скрытое духовное беспокойство, проступающее также через соотнесение с архетипами апостола Фомы, богословов Фомы Аквинского и Фомы Кемпийского ${ }^{14}$, наконец, школяра Франуса Вийона (Шульц, 2017). В таком случае сюжет приобретает элементы агиографии.

Интересно сопоставление Демковой сюжетов Вия и древнерусской Повести о некоем убогом отроце (XVII в.), включающей заметные агиографические элементы. Отмечая близость мотива отпевания заклятой умершей у Гоголя и у неизвестного автора Повести..., Демкова указывает, что герой XVII века, в отличие от Хомы, читает без страха, „не устрашась царевны” (статус героини отчасти коррелирует со статусом знатной гоголевской панночки), а в ночь третьего чтения даже освобождает ее от заклятия. Царевна становится его невестой, что совпадает также с мотивами так называемого „некнижного” жития Николая Чудотворца (где святой исцеляет беснующуюся в храме девицу) и с мотивами сказки Иван купеческий сын отчитывает ияаревну, где описано оживление персонажем мертвой царевны, изгнание из нее злых духов и последующий брак героев (Демкова, 1989, т. 42, с. 404, 406).

На фоне сюжетного завершения Повести о некоем убогом отроие Гоголь обрывает и в итоге снимает первоначально заданные в Вие агиографические параллели, приводя финал к негативности в их отношении. Впрочем, надо обратить внимание на замечание Фомичева: „Но в окончательной редакции (1842-го года) Гоголь все же спас его [Хомы. - С. Ш.] душу. Здесь важно отметить деталь, ранее в тексте отсутствующую. (...) Душа (...) Хомы вылетела до второго петушьего крика, а стало быть, не застряла в стенах вместе с нечистью” (Фомичев, 1995-1996, с. 445).

К агиографии, также генетически, восходит модель рыцарского романа, например, в тексте анонимного средневекового стихотворного романа Роберт Дьявол (Михайлов, 1976, с. 146; 310) (в Ревизоре упоминается опера Мейербера с таким же названием). Хома сопоставим с „рыцарем” - через несколько ироническое высказывание Гете о „рыцарях” XVI в. (а это тот век, когда был основан Братский монастырь в Киеве, где расположена бурса Хомы), о чем мы уже писали ${ }^{15}$. В Тарасе Бульбе казаки прямо названы „рыцарями”.

Хома, безусловно, - „рыцарь” в достаточно пародийном, мениппейном значении, но в заданном качестве представителя Церкви - он, можно сказать, „рыцарь-монах”16 (такой тип часто встречался среди крестносцев), и тут уже почти нет пародийности. Неизменная данность модели „пространства рыцарского поиска - глухая (...) дорога” (Михайлов, 1976, с. 181) - вспомним в связи с этим весомость самого хронотопа большой дороги, по которой плутают и с которой сбиваются школяры в Вие. Кроме того, учтем, что в рамках рыцар-

\footnotetext{
14 Гоголь был хорошо знаком с трактатом последнего О подражании Христу.

15 Хома Брут и Франсуа Вийон (Шульц, 2017).

16 Блок назвал свою статью о Соловьеве именно „Рыцарь-монах”. Заметим, что речь идет о философе (статус Хомы).
} 
ского эпоса существовали не только прямые манифестации жанра, но также „иронические и пародийные произведения”, например, анонимный „Рыцарь двух шпаг” (Михайлов, 1976, с. 51), жанровый вариант которых в аспекте исторической поэтики косвенно „проступает” в Вие. Названные „иронические и пародийные произведения” карнавализованы, подобно будущим жанровым моделям Вия и Замка.

Один из эпизодов рыцарского романа Кретьена де Труа Ивэйн, или Рьциарь со львом предвосхищает сюжетный мотив Вия, когда Хома видит в церкви каплю крови на лице умершей панночки:

Кровоточит мертвец в гробу,

Алеет снова кровь на лбу -

Наивернейшая примета:

Убийца, значит, рядом где-то (...)

Мертвец как будто хмурит брови,

Окрашенные струйкой крови.

(Тpya, 1974, c. 56)

И далее:

Никак вассалы не поймут,

Что происходит в этом зале.

Переглянулись и сказали:

„Когда убийца среди нас,

Его, наверно, дьявол спас

От нашей справедливой кары.

Тут явно дьявольские чары!

(Tpya, 1974, c. 56)

В цитате инфернальность приписывается убийце, тогда как у Гоголя инфернальна „убитая” панночка; но в церкви погубить школяра собирается уже она сама. Совпадение мотива выступания крови у убитого лица при нахождении рядом убийцы, однако, налицо. Хома все равно остается (невольным) убийцей, а при редукции христианского пласта Вия до мифо-фольклорного (языческого) начала панночка способна превратиться в нечто более позитивное, например, языческую „Великую мать” и т.п.

Отдельные рыцарские романы ретроспективно называют „готическими”, например, французский анонимный роман Гибельный погост (XIII в.), где герой сражается с нечистой силой, место действия - ночное кладбище с разверзающимися могилами (Михайлов, 1976, с. 215). Ср.: в Вие „летающий” гроб панночки, способной покидать его, и сами сцены поединка Хомы с силами ада; эти эпизоды - свидетельство в пользу рецепции Гоголем модели рыцарского „готического” романа.

Роль для Вия модели иного, но родственного вышеназванному, жанра (классического готического романа конца XVIII - начала XIX в.) уже справедливо отмечалась еще Магомедовой (2009) при сопоставлении с Монахом Льюиса.

Аргументами в пользу этого выступают мотивы дьявольских соблазнов в гоголевской повести, наличие там фигуры, готовящейся стать духовным лицом, 
присутствие образа заброшенной церкви, где происходят мистические бдения и искушения.

Говоря о героях средневекового романа в целом, Мелетинский указывает, что те „не столько (...) характеры, сколько художественные конструкции” (Мелетинский, 1983, с. 7); то же справедливо в отношении классического готического романа. Герои рыцарского и готического романов, „переходящие” (вместе с отдельными иными составляющими их жанровых моделей), в рамках исторической поэтики, к Гоголю, становятся у писателя уже не только „конструкциями”, т.е. даны не только в рамках заданности сюжета и всей топики. Мир гоголевских героев наполняется духовно-психологическим содержанием, гоголевские протагонисты становятся резко индивидуализированными, неповторимыми, но сохраняя, вместе с тем, нечто от „конструкции” именно благодаря связям с указанными жанровыми моделями.

В жанровом составе романа Кафки также задана модель готического романа: прежде всего через заглавный образ загадочного Замка, чья историческая семантика/топика неизбежно хранит память о романных моделях литературной готики. У Кафки Замок, образ которого особо выдвинут уже через заглавие романа, так и не становится ареной действия, о нем лишь рассказывают, на предписания оттуда только ссылаются. Тем не менее образ замка в качестве некоей „фигуры фикции” (термин Андрея Белого о Гоголе) - центр притяжения всех сил, действующих в романе. Только ли человеческие это силы? В любом случае не приходится сводить образ замка к какой-то непосредственной конкретике (в том числе антропной), вопреки, например, позиции Гулыги, писавшего в связи с кафковским Замком лишь о критике писателем мира „бюрократии” (Гулыга, 1988). Бюрократизация выступает в Замке и в Замке лишь частной эмблемой общемирового абсурда.

На фоне топики бюрократизации характерен почти „канцелярский”, „официально-деловой стиль”, используемый Гоголем при описании им своего „идеального государства”, например: „Нужно вспомнить человеку, что он вовсе не материальная скотина, но высокий гражданин высокого небесного гражданства. Покуда он хоть сколько-нибудь не будет жить жизнью небесного гражданина, до тех пор не придет в порядок и земное гражданство” (уже цитировавшийся черновик неотправленного письма к Белинскому, т. 14, с. 392). Гоголь нередко сугубо духовные категории описывал в терминах несколько бюрократизированных, что объяснимо его полным доверием к содержанию всяческих мифо-политических институций, от архаики до его эпохи.

Как Хома - символ человека вообще (ср. латинское ${ }^{17}$ обозначение человека homo), так и К. становится из некоей „эманации” самого Кафки - символом всякого человека.

Если использовать термины Манна, допустимо утверждение: в кафковском романе есть некая фантастика (это поиски и злоключения землемера К.), но нет носителя фантастики (Манн, 1988). Вместе с тем, исходя из другого ракурса, высказывание переворачивается: есть носитель фантастики (Замок), но самой

17 Вий знаменит своими латинскими именами и „античным колоритом” в целом. 
фантастики словно нет, лишь абсурд вместо нее. Образ Замка, могущий выступать, согласно готической традиции, именно „носителем”, „источником” разнообразной фантастики, настойчиво задан, а само „сверхъестественное” в прямом виде отсутствует.

Есть нечто ужасающее, пугающее в таком выдвижении некоей образной фигуры, чьим именем названо все произведение, но о которой персонажи и читатели узнают только из пересказов, слухов, настраивающих то на надежду в реальность Замка, то на скепсис. Вот эта „готическая” - „готическо-экспрессионистическая” (с учетом экспрессионизма Кафки) - ужасаемость заглавной образной фигуры романа и есть то ли фантастика без ее носителя, то ли носитель фантастики без самой фантастики.

В связи с отсутствием в Замке прямо декларированной фантастики уместно привести замечание Бланшо:

К. тоже хочет добиться цели, но ею ни является ни место, в котором он все же нуждается, ни Фрида, к которой он испытывает привязанность; он хочет добиться таковой не скучными способами, требующими терпения и умеренной общительности, но (...) способом невозможным и к тому же ему самому неизвестным. (...) Может, в этом его заблуждение. В романтической страсти к абсолютному? (...) К. выбирает невозможное, потому что неким изначальным решением он был лишен всякой возможности. (...) он был удален из мира, из своего мира, обречен на отсутствие мира, предан изгнанию, в котором нет места для подлинной жизни. Блуждать - вот его закон. Неудовлетворенность К. - это и есть способ блуждания, его выражение. (...) и все же, идти все дальше в ошибочном направлении - это его единственный повод для надежды.

Прав он или не прав? Он не может этого знать, и мы также не знаем.

(Бланшо, 1988, с. 141)

Модель рыцарского романа в Замке проступает также через символическиэмблематический образ заглавия: ведь один из важных хронотопов в рыцарском романе вообще - замок, различные замки. Кроме того, к реализации жанровой модели рыцарского романа у Кафки причастны мотив „духовного приключенчества" (Гегель) К. и духовного поиска автора/нарратора, а также важный хронотоп символической дороги - не только жизненного пути индивидов, но и их пути между „мирами”, уровнями мироздания.

Заметный бытовой фон коррелирует у Кафки с не столь явными внебытовыми - почти волшебными, как в рыцарском романе - приметами, „сигналами”, деталями, действиями. Все эти приметы и детали двойственны: они существуют в своей внесимволической фактичности и в своей сложной многосмысленной символичности.

Искомый у Кафки Замок нельзя не сопоставить с замком Грааля из рыцарских романов де Труа (Роман о Персевале, Роман о Гавэйне) и наследующего им фон Эшенбаха (Париифаль). У Вольфрама мир Грааля, мистической христианской святыни, по замечанию Михайлова,

благодаря своей идеальности принимает на себя основные черты королевства Артура. (...) Королевство Грааля имеет вполне внятные этические и практические цели. Оно не только хранит волшебный камень, обладающий многими чудесными свойствами, но и культивирует определенные нравственные идеалы (...) Королевство Грааля имеет (...) 
достаточно ясную программу. Обладает оно и четкой организацией. (...) Мораль Грааля антисословна и наднациональна (...) Содружество Грааля - это сообщество благородных духом, мужественных и честных, и потому практически оно открыто для многих, не только для ставшего праведным христианином и постигшего суть Бога Парцифаля, но и для язычника Фейрефица.

(Михайлов, 1974, с. 21-22)

У Вольфрама дана мотивировка закрытости замка Грааля для его героя: „Парцифаль забыл о сострадании и не исцелил короля Анфортаса, и за это прегрешение против человечности путь в страну Грааля юному рыцарю оказывается заказан” (Михайлов, 1974, с. 22). Ср. злоключения К., не совершившего никаких одиозных поступков, однако же, не могущего попасть в свой Замок.

Мотиву неизменной обращенности К. к поиску Замка (как эквиваленту духовного поиска) соответствует девиз духовного вертикального движения протагониста романа Кретьена Ивэйн, или рыциарь со львом. По признанию Ивэйна:

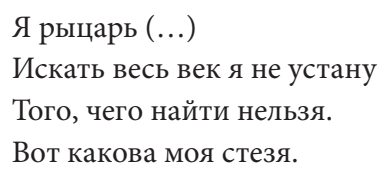

К. также ищет то, „чего найти нельзя”.

Дон Кихот представлял собой пародию на рыцарский роман (сохраняя в себе отдельные элементы жанра romance) и вместе с тем это - первый образец социально-бытового романа Нового времени (жанр novel) (см.: Мелетинский, 2001, с. 111-113); Замок же - своего рода пародия на Дон Кихота, и в чем-то возвращение к досервантесовскому типу романа (romance). Присущая Дон Кихоту линия социально-бытового романа в ключе Нового времени (жанр novel), в Замке разрушается, превращается в мираж и мнимость, уступая первенство другой линии - туманно-мистической, фигуральной, условной, разорвано-символической (romance). Romance - роман средневекового типа, „романтизированный”, включает элементы мифологичности и сказочности.

По наблюдению Кундеры, „Дон Кихот выехал навстречу миру, широко распахнутому перед ним. Он мог спокойно проникнуть в него и вернуться домой, когда захочет. Первые европейские романы представляют собой путешествия по миру, который кажется бескрайним"; однако уже в Жаке-фаталисте Дидро герои „находятся во времени, лишенном начала и конца, в пространстве, лишенном границ, посреди Европы, для которой будущее нескончаемо” (Кундера, 2013 , с. 18). У Кафки соединяются хронотопические планы, восходящие к Дон Кихоту и Жаку-фаталисту; последний текст в данном случае представляет собой только частность более общих и более сложных романных моделей, сходным с ним, прежде всего предромантических и романтических.

Родственность хронотопических и жанрово-мотивных моделей, аллюзии на жанровые модели архаики, средневековья, Ренессанса, предромантизма, романтизма, погруженность этих моделей и аллюзий в сложный историософский и культурфилософский контекст, карнавализация, преобладание мениппейно- 
го начала - все эти присущие Вию и Замкучерты способствуют особой близости творчества двух великих мистических авторов.

Неоконченность Замка воспринимается читателем в качестве почти не замечаемой, даже закономерной и необходимой. „Неоконченность” является органичной для этого текста (и для всего творчества Кафки), свидетельствуя в том числе о перерастании героем рамок художественного произведения, случаи чего отмечены Бахтиным (Бахтин, 1996, т. 5, с. 304-305). „Перерастание” подразумевает тут также модернистское вдвижение жизни в горизонт искусства (не наоборот: не искусства в горизонт жизни). Сходная органическая „неоконченность” процесса творчества, что отметил Белый, свойственна Гоголю (Белый, 1996, с. 339; см. также: Шульц, 2017, с. 217).

\section{Литература}

Бахтин, М. (1996). Собрание сочинений: в 7 m. Т. 5, Москва: Русские словари.

Белый, А. (1996). Мастерство Гоголя. Москва: МАЛП.

Беньямин, В. (2000). Ф. Кафбка. Москва: Ad Marginem.

Бланшо, М. (1998). От Кабки к Кафке. Москва: Логос.

Бодлер, Ш. (1993). Цветы Зла. Стихотворения в прозе. Пер. с фр. П. Якубович. Москва: Высшая школа.

Бочаров, С. (2007). Филологические сюжеты. Москва: Языки славянских культур.

Брод, М. (2000). О Ф. Кабке. Санкт-Петербург: Академический проект.

Брод, М. (2003). Ф. Кабка. Узник абсолюта. Москва: Центрполиграф.

Виноградов, И., Воропаев В. (2009). Комментарии. В: Гоголь, Н. В. Полное собрание сочинений и писем: в 17 m. Т. 2. Москва; Киев: Издательство Московской Патриархии, с. 646-656.

Гоголь, Н. (2009-2010). Полное собрание сочинений и писем: в 17 m. Москва; Киев: Издательство Московской Патриархии.

Гулыга, А. (1988). В призрачном мире бюрократии: Франц Кафка и его роман „Замок”. Иностранная титература, № 3, с. 217- 223.

Гуссерль, Э. (1996). Начало геометрии. Пер. с нем. М. Маяцкий. Москва: Ad Marginem.

Делез, Ж., Гваттари, Ф. (2015). Каффка: за малую литературу. Москва: Институт общегуманитарных исследований.

Демкова, Н. (1989). Из истории русской повести XVII века. Об одной параллели к повести Н. В. Гоголя „Вий”. (Повесть о некоем убогом отроие). В: Лихачев, Д. С. (ред.). Труды отдела древнерусской литературы. Т. 42. Ленинград: Наука, с. 401-408.

Достоевский, Ф. (1983). Полное собрание сочинений и писем: в 30 m. Т. 25. Ленинград: Наука.

Жирар, Р. (2010). Козел отпущения. Пер. с фр. Г. Дашевского. Санкт-Петербург: Издательство И. Лимбаха.

Зенкин, С. Н. (2012). Небожественное сакральное:теория и художественная практика. Москва: РГГУ.

Иваницкий, А. И. (2000). Власть государства и родителя у Гоголя и Кафки. В: Иваницкий, А. И. (ред.). Гоголь. Морфология земли и власти. Москва: Российский государственный гуманитарный университет, с. 152-158.

Камю, А. (1990). Записные книжки. В: Камю, А. Творчество и свобода. Статьи, эссе, записныле книжки. Пер. с фр. О. Гринберг и В. Мильчиной. Москва: Радуга, с. 193-555.

Камю, А. (1990). Миф о Сизифе. Эссе об абсурде. В: Камю, А. Бунтующий человек. Москва: Политиздат, с. 23-92. 
Кафка, Ф. (1991). Замок. В: Кафка, Ф. Замок. Новелль и притчи. Письмо отиу. Письма Милене. Пер. Р. Райт-Ковалевой. Москва: Политиздат, с. 15-280.

Кафка, Ф. (1991). Из дневников. В: Кафка, Ф. Америка: процесс: из дневников. Пер. Е. Кацевой. Москва: Политиздат, с. 429-596.

Кафка, Ф. (1991). Из разговоров Г. Яноуха с Ф. Кафбой. В: Кафка, Ф. Замок. Новеллы и притчи. Письмо отиу. Письма Милене. Пер. Е. Кацевой. Москва: Политиздат, с. 545-568.

Труа де, К. (1974). Ивэйн, или Рыцарь со львом. В: Средневековый роман и повесть. Пер. В. Микушевича. Москва: Художественная литература, с. 31-152.

Кузин, И. В. (2015). К вопросу становления концепции „взгляд” в философии Ж.-П. Сартра. Вопросы философии, № 2, с. 169-178.

Кундера, М. (2013). Искусство романа. Пер. с фр. А. Смирновой. Санкт-Петербург: Азбукаклассика.

Лескова, Е. В. (2015). Жанровая специфика притчи и мениппеи в романах Ф. Кафки „Процесс” и Ф. М. Достоевского „Братья Карамазовы”. Вестник Вятского государственного гуманитарного университета. Филологические науки, № 1, с. 114-118.

Лосев, А. Ф. (1994). Диалектика мифа. В: Лосев, А. Ф. (ред.). Миф - Число - Сущңость. Москва: Мысль, с. 5-216.

Лотман, Ю. М. (1988). Художественное пространство в прозе Гоголя. В: Лотман, Ю. М. (ред.). В школе поэтического слова. Пушкин. Лермонтов. Гоголь. Москва: Азбука, с. 293-325.

Магомедова, Д. М. (2009). Готическая традиция в повести Н. В. Гоголя Вий. Гоголевский сборник. Вып. 3 (5), с. 18-29.

Манн, Ю. В. (1999). Встреча в табиринте: Ф. Кафка и Н. Гоголь. Вопросы литературы. № 2, c. $162-186$.

Манн, Ю. В. (1988). Поэтика Гоголя. 2-е изд. Москва: Худ. литература.

Манн, Ю. В. (2007). Творчество Гоголя. Смысл и форма. Санкт-Петербург: СПбГУ.

Меерсон, О. А. (2009). Персонализм как поэтика: литературный мир глазами его обитателей. Санкт-Петербург: Пушкинский дом.

Мелетинский, Е. М. (2001). От мифа к литературе. Москва: РГГУ.

Мелетинский, Е. М. (1983). Средневековыци роман. Москва: Наука.

Мережковский, Д. С. (1991). Гоголь и черт. В: Мережковский, Д. С. (ред.). В тихом омуте. Москва: Советский писатель, с. 213-309.

Михайлов, А. В. (1997). Из истории характера. В: Михайлов, А. В. (ред.). Языки культурыь. Москва: Языки русской культуры, с. 176-210.

Михайлов, А. Д. (1974). Роман и повесть высокого средневековья. В: Средневековый роман и повесть. (Библиотека всемирной литературы; серия первая. Т. 22). Москва: Художественная литература, с. 5-28.

Михайлов, А. Д. (1976). Франиузский рыцарский роман и вопросы типологии жанра в средневековой титературе. Москва: Наука.

Набоков, В. В. (1998). Ф. Кабка. В: Набоков, В. В. Лекции по зарубежной литературе. Москва: Независимая газета, с. 323-364.

Подорога, В. А. (1995). Выражение и смысл. Ландиафтные миры философии. Москва: Ad Marginem.

Смирнова-Россет, А. О. (1990). Воспоминания о Н. В. Гоголе. В: Смирнова-Россет, А. О. Воспоминания. Письма. Москва: Правда, с. 407-454.

Тамарченко, Н. Д. (2011). „Эстетика словесного творчества” М. М. Бахтина и русская философско-филологическая традиция. Москва: Изд. Кулагиной.

Теккерей, У. (1991). Виргинцы. Т. 1. Москва: Правда. 
Толстая, С. М. (1995). Обмирания. В: Славянская мифология. Словарь. Москва: Эллис Лак, c. $278-279$.

Фарино, Е. (1979). Структура поездки Чичикова. Russian Literature, т. 7. № 6, с. 614-616.

Фомичев, С. А. (1995-1996). Повесть Н. В. Гоголя Вий (заметки комментатора). В: Панов,

С. И. (ред.). Новые безделки: сборник статей к 60-летию В. Э. Вацуро. Москва: НЛО, c. 444-447.

Хабермас, Ю. (2008). Филособский дискурс о модерне. Пер. с нем. М. М. Беляева и др. Изд. 2-е Москва: Весь Мир.

Шульц, С. А. (2018). Ф. Кафка и Л. Н. Толстой (по поводу „Воспоминания о дороге на Кальду"). Opera Slavica, т. 28, № 1, с. 37-47.

Шульц, С. А. (2017). Мотивы русской волшебной и бытовой сказки в повести Гоголя Вий. Wiener Slawistischer Almanach. Bd.79, c. 155-164.

Шульц, С. А. (2017). Поэма Гоголя „Мертвые души”: внутренний мир и литературно-философские контексты. Санкт-Петербург: Алетейя.

Шульц, С. А. (2017). Хома Брут и Франсуа Вийон. Человек, № 2, с. 144-154.

Coates, R. (1998). Christianity in Bakhtin. God and the Exiled Author. Cambridge: Cambridge University Press.

Fetzer, L., Lawson R. H. (1978). Den Tod zur Schau gestellt: Gogol und Kafkas Hungerkünstler. Modern Austrian Literature, т. 11, № 3/4 (Special Franz Kafka Issue), c. 167-178.

Müller, M. (1992). Wohin gehst du Kleines Kind im Walde? über Erinnerungen an die Kalda bahn. B: Zimmerman, H. D. (ред.), Nach erneuter Lektüre F. Kafkas Der Prozess. Würzburg: Königshausen und Neumann, c. 75-83.

Parry, I. F. (1953). Kafka and Gogol. German Life and Letters, № 6 (2), c. 143. 